\title{
The Residual Effect of Pre-Rice Green Manuring on a Succeeding Wheat Crop (Triticum aestivum L.) in the Rice-Wheat Cropping System in Banke, Nepal
}

\author{
Roshana Gautam (i), ${ }^{1}$ Chandeshwor Prasad Shriwastav, ${ }^{2}$ Sarita Lamichhane, \\ and Bandhu Raj Baral ${ }^{3}$ \\ ${ }^{1}$ Agriculture and Forestry University, Rampur, Nepal \\ ${ }^{2}$ College of Natural Resource Management, Puranchaur, Kaski, Nepal \\ ${ }^{3}$ Nepal Agriculture Research Council, Kathmandu, Nepal \\ Correspondence should be addressed to Roshana Gautam; rosanagautam7@gmail.com
}

Received 6 June 2021; Revised 8 November 2021; Accepted 17 November 2021; Published 8 December 2021

Academic Editor: Vijay Gahlaut

Copyright (c) 2021 Roshana Gautam et al. This is an open access article distributed under the Creative Commons Attribution License, which permits unrestricted use, distribution, and reproduction in any medium, provided the original work is properly cited.

\begin{abstract}
Rice-wheat is the most widely used cropping pattern in Nepal. This cereal-based cropping system is highly nutrient exhaustive and unsustainable from a soil management perspective. They contribute neither nitrogen nor biomass to the soil. The net effect is the export of nutrients from the soil. The unused period between wheat harvest and rice transplanting is the summer fallow, and the incorporation of green manure during this short period increases the yield of both crops and improves the soils chemical properties. Altogether, there were 9 treatments and 3 replications with the randomized complete block design (RCBD). Dhaincha, sun hemp, black gram, cowpea, mung bean, and rice bean were used as pre-rice green manure. No chemical fertilizers were used for the green manure, and in wheat, 150:50:50 NPK kg/ha was applied. Goat manure was applied at the rate of $10 \mathrm{t} / \mathrm{ha}$. The main objective of the study is to ascertain the residual effect of pre-rice green manuring on the chemical properties of the soil and the yield attributes of the succeeding wheat crops. The chemical properties of the soil were analyzed before and after the harvesting of wheat, and the yield attributes parameters were analyzed. The result showed that the green manure-treated plots gave a significantly higher yield as compared to solely chemical fertilizers-treated plots. The maximum grain yield was obtained from black gram $(5.870 \mathrm{t} / \mathrm{ha})$. There was a $39.76 \%$ increase in the grain yield in the black gram-incorporated plots as compared to the onlychemical fertilizers-treated plots. There was a highly $(<0.001)$ significant difference in the soil organic matter of the green manuretreated plots and the only-chemical fertilizers-treated plots. The sun hemp-incorporated plot increased the soil organic matter by $71 \%$ when compared to the only-chemical fertilizers-treated plot. There was no significant residual effect of pre-rice green manuring on the soil $\mathrm{pH}$ in a one-cropping season. However, there was a significantly higher residual effect of the green manure on the soil's total nitrogen content in all green manure-treated plots. It was found to be the highest $(0.087 \%)$ in pre-rice dhaincha. The overall results indicate that the incorporation of pre-rice green manuring improved the soil's chemical properties and increased the grain yield of the succeeding wheat crops in a rice-wheat cropping system.
\end{abstract}

\section{Introduction}

Wheat (Triticum aestivum L.) is a major cereal crop cultivated globally. In the context of Nepal, it is regarded as the third most valuable cereal crop following rice and maize. Feeding the growing population with the production of wheat is a major global threat in most of the countries [1]. Kumar and
Sharma [2] reported that the growth of a leguminous crop in the previous season affects the yield and yield attributing parameters of wheat. Green manuring is the practice of using the undecomposed green plant material, grown in situ or cut and brought in for incorporation, to improve soil productivity. The incorporation of pre-rice green manuring significantly increased the nutrient status of the soil, and also, it 


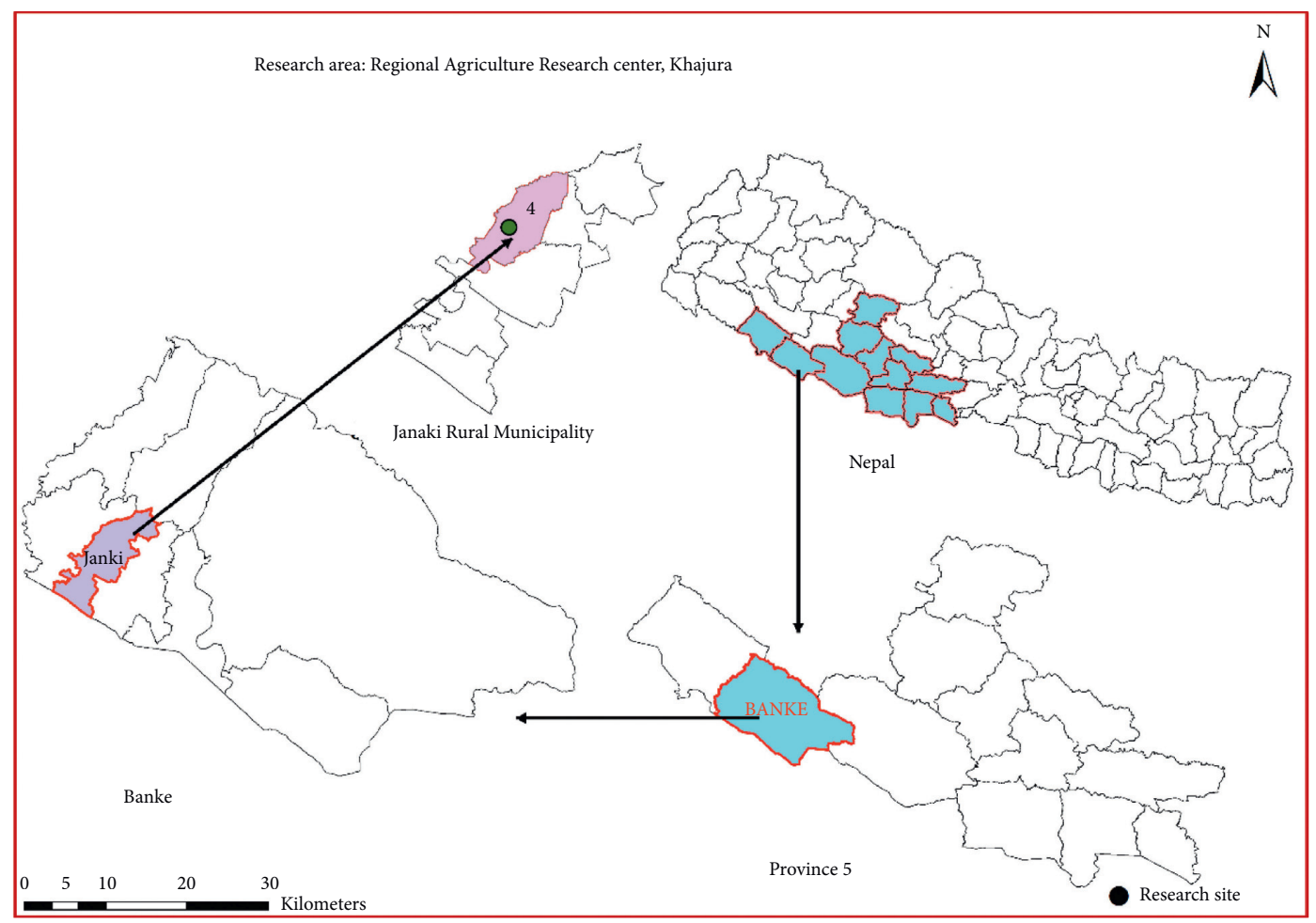

FIgURE 1: Location of experimental site at Regional Agriculture Research Station, Khajura.

contributed to the rice grain [3]. A continuous intensive cultivation led to the detachment and leaching of the nutrients from the root zone area and resulted in the reduction of the organic matter content of the soil. Hence, the incorporation of green manuring is the best option to restore soil fertility as it is ecofriendly, nutrient-rich, and easily biodegradable in nature [4]. After the harvest of winter crops, the period available until the next rainy season crops can be used for the plantation of rapidly growing green manuring. The incorporation of legumes green manure in a rice-based cropping system has been widely studied.

The unused remaining time after harvesting wheat and before transplanting the rice seedlings is sufficient for the growth of short-duration legume crops. Along with improving the soil fertility status, the incorporation of green manure reduces the demand for external chemical fertilizers. It improves soil fertility by the direct addition of nitrogen, and it improves soil structure by the addition of organic matter. The higher content of organic matter helps to bind the soil particles and form stable soil aggregates that ameliorate the chemical, physical, and biological characteristics of the cultivating soil.

\section{Materials and Methods}

2.1. Site Description. The experiment of field work was accomplished at Regional Agriculture Research Station (RARS), Khajura, Banke, Nepal. The research was conducted from November 2018 to April 2019. It is geographically situated at $80^{\circ} 37^{\prime \prime}$ East longitude and $20^{\circ} 06^{\prime \prime}$ North latitude at an elevation of approximately 181 meters above the sea level (masl). After harvesting rice, the soil samples were taken from 27 plots using the soil auger before sowing the wheat. The soil was taken from $15 \mathrm{~cm}$ deep. The nature of the soil was clay loam. The soil of each plot was analyzed to determine the initial concentration of the total nitrogen content of the soil, soil organic matter, available phosphorus, available potassium, and soil $\mathrm{pH}$. The location of the experimental site is shown in Figure 1.

2.2. Treatments. The treatment consists of green manuring, inorganic fertilizers, and organic manures (goat). The organic manure was applied in one plot treatment $\left(T_{3}\right)$ at the rate of 10 tons/ha during wheat sowing. The experiment consists of three replications with nine treatments, and the layout was in a randomized complete block design (RCBD). The treatment details are shown in Table 1.

The wheat was sown in rows with a spacing of 25 centimeters $(\mathrm{cm})$. The area of each plot was $20 \mathrm{~m}^{2}$. There were 19 rows of wheat in each plot with a $5 \mathrm{~m}$ length. A gap of 1 meter was maintained between the blocks and the plots. There was no application of chemical fertilizers in the green manures. The green manure was sown during the fallow period, and the in situ incorporation was done before rice transplanting. While sowing wheat, the recommended dose of phosphorus and potassium was applied to the soil. The application of nitrogen was done in three split doses, the first on the 21st day after sowing, the second just before flowering, and the last one just before heading. Before sowing and after harvesting wheat, the soil organic matter, soil total nitrogen, soil available phosphorus, potassium, and soil $\mathrm{pH}$ were determined. The soil analysis method is shown in Table 2. 
TABLE 1: Treatments details.

\begin{tabular}{|c|c|}
\hline Treatments & Treatment description \\
\hline$T_{1}$ & Rice-wheat-fallow (no nutrients application in rice and wheat) \\
\hline$T_{2}$ & Rice-wheat-fallow (chemical fertilizers application in rice NPK@100:30:30 kg/ha and wheat NPK @ 150:50:50 kg/ha) \\
\hline$T_{3}$ & Rice-wheat-fallow (organic manure in rice and wheat@10 ton/ha) \\
\hline$T_{4}$ & Rice-wheat-dhaincha (rice NPK@100:30:30kg/ha, wheat NPK@150:50:50kg/ha) \\
\hline$T_{5}$ & Rice-wheat-sun hemp (rice NPK @100:30:30 kg/ha, wheat NPK @ $150: 50: 50 \mathrm{~kg} / \mathrm{ha}$ ) \\
\hline$T_{6}$ & Rice-wheat-cowpea (rice NPK @100:30:30kg/ha, wheat NPK @ 150:50:50kg/ha) \\
\hline$T_{7}$ & Rice-wheat-black gram (rice NPK @100:30:30 kg/ha, wheat NPK@ $150: 50: 50$ kg/ha) \\
\hline$T_{8}$ & Rice-wheat-mung bean (rice NPK @100:30:30 kg/ha, wheat NPK @ 150:50:50 kg/ha) \\
\hline$T_{9}$ & Rice-wheat-rice bean (rice NPK @100:30:30kg/ha, wheat NPK@150:50:50 kg/ha) \\
\hline
\end{tabular}

TABle 2: Soil analysis method.

\begin{tabular}{lc}
\hline Soil parameters & Analysis method $(0-15 \mathrm{~cm}$ depth) \\
\hline Soil pH & Glass-electrode $\mathrm{pH}$ meter method [5] \\
Soil texture & Bouyoucos hydrometer method [6] \\
Soil organic matter & [7] Kjeldahl distillation [8] \\
Soil total nitrogen & Modified Olsen's bicarbonate method [9] \\
Available phosphorus in soil & Ammonium acetate method [10] \\
Available potassium in soil & \\
\hline
\end{tabular}

TABle 3: Initial chemical properties of soil $(0-15 \mathrm{~cm})$ at RARS, Khajura.

\begin{tabular}{lcccccccccc}
\hline Treatments & Av. $\mathrm{P}_{2} \mathrm{O}_{5}$ & $\mathrm{SD} \mathrm{P}_{2} \mathrm{O}_{5}$ & $\mathrm{Av} . \mathrm{K}_{2} \mathrm{O}$ & $\mathrm{SD} \mathrm{K} \mathrm{K}_{2} \mathrm{O}$ & $\mathrm{Av} . \mathrm{SOM}(\%)$ & SD SOM (\%) & Av. pH & SD pH & Av. N (\%) & SD N (\%) \\
\hline$T_{1}$ & 0.026 & 0.004 & 6.497 & 0.269 & 1.410 & 0.429 & 6.833 & 0.058 & 0.050 & 0.010 \\
$T_{2}$ & 0.041 & 0.001 & 8.140 & 0.333 & 2.320 & 0.478 & 6.867 & 0.115 & 0.060 & 0.010 \\
$T_{3}$ & 0.053 & 0.003 & 8.967 & 0.472 & 2.609 & 0.344 & 6.800 & 0.000 & 0.065 & 0.022 \\
$T_{4}$ & 0.056 & 0.005 & 11.867 & 0.757 & 3.780 & 0.220 & 6.800 & 0.000 & 0.080 & 0.010 \\
$T_{5}$ & 0.045 & 0.003 & 8.737 & 0.594 & 3.967 & 0.365 & 6.900 & 0.173 & 0.080 & 0.000 \\
$T_{6}$ & 0.043 & 0.001 & 8.733 & 0.562 & 3.436 & 0.340 & 6.833 & 0.058 & 0.073 & 0.006 \\
$T_{7}$ & 0.038 & 0.003 & 8.423 & 0.447 & 3.150 & 0.046 & 6.800 & 0.000 & 0.067 & 0.012 \\
$T_{8}$ & 0.054 & 0.005 & 9.020 & 0.079 & 3.064 & 0.519 & 6.867 & 0.115 & 0.073 & 0.006 \\
$T_{9}$ & 0.058 & 0.003 & 9.200 & 0.452 & 3.610 & 0.040 & 6.833 & 0.058 & 0.073 & 0.006 \\
\hline Total & 0.045 & 0.010 & 8.840 & 1.396 & 3.030 & 0.832 & 6.830 & 0.079 & 0.060 & 0.013 \\
\hline
\end{tabular}

2.3. Chemical Properties of Soil before Wheat Sowing. The initial chemical properties of soil are shown in the Table 3.

2.4. Statistical Analysis. The kobo collect tool was used from the beginning of the experiment to record the data on plant height, tillers number, and the length of panicle on the successive interval of $21,42,63,84$, and 105 days, respectively. The data were directly extracted from the kobo collect. Other data, such as plant height, panicle length, grain yield, filled grain, and unfilled grain at the time of harvesting, were recorded manually, and the data were subjected to the analysis of variance (ANOVA) using the Gen-stat software. Duncan's multiple range test at a 5\% level of significance was used for the mean separation.

\section{Results and Discussion}

\subsection{Effect on Yield and Yield Attributing Parameters}

3.1.1. Plant Height. There was no significant difference in the plant height between the green manure-with-chemical fertilizers-treated plots and the only-chemical fertilizerstreated plots. The maximum plant height $(102.65) \mathrm{cm}$ was obtained from the black gram-treated plot, which was statistically at par with all green manure-incorporated plots and chemical fertilizers-treated plots. It has been well-established that the application of green manure with the combined use of chemical fertilizers promotes the wheat plant's height as it increases the availability of major nutrients, especially $\mathrm{N}$, which has a positive effect on the plant's height. These findings are in accordance with the result of [11] who had observed an increased plant height in both crops by the incorporation of green manure along with chemical fertilizers. A similar result was obtained by Nawaz et al. [12]. Indeed, the incorporation of legumes green manuring increased the uptake of nitrogen $(\mathrm{N})$, phosphorus $(\mathrm{P})$, potassium $(\mathrm{K})$, zinc $(\mathrm{Zn})$, iron $(\mathrm{Fe})$, manganese $(\mathrm{Mn})$, and copper $(\mathrm{Cu})$. It might be the possible reason for an increase in the plant's height. Black gram as a preceding crop had a relatively higher residual effect than the mung bean on the succeeding wheat crop [13]. The incorporation of dhaincha and cowpea green manure increased the yield of the first (rice) and second succeeding crops (maize) by $21 \%$ and $4 \%$ in the first year and by $38 \%$ and $13 \%$ in the second year of the experiment done at Selangor, Malaysia [14]. A similar result 
TABLE 4: Effect of chemical fertilizers and green manure treatments on the plant height, spike length, number of grains/spike, and 1000-grain weight.

\begin{tabular}{|c|c|c|c|c|}
\hline Treatments & Plant height $(\mathrm{cm})$ & Spike length $(\mathrm{cm})$ & No of grains/spike & 1000 -grain weight $(\mathrm{g})$ \\
\hline$T_{1}$ & $74.23^{\mathrm{c}}$ & $7.47^{\mathrm{b}}$ & $26^{\mathrm{b}}$ & $40.37^{\mathrm{d}}$ \\
\hline$T_{2}$ & $100.26^{\mathrm{a}}$ & $9.70^{\mathrm{a}}$ & $37^{\mathrm{a}}$ & $43.10^{\mathrm{b}}$ \\
\hline$T_{3}$ & $83.54^{\mathrm{b}}$ & $8.01^{\mathrm{b}}$ & $32.87^{\mathrm{ab}}$ & $42.10^{\mathrm{c}}$ \\
\hline$T_{4}$ & $98.75^{\mathrm{a}}$ & $9.79^{\mathrm{a}}$ & $40.53^{\mathrm{a}}$ & $44.01^{\mathrm{a}}$ \\
\hline$T_{5}$ & $100.67^{\mathrm{a}}$ & $9.67^{\mathrm{a}}$ & $41.87^{\mathrm{a}}$ & $44.70^{\mathrm{a}}$ \\
\hline$T_{6}$ & $100.70^{\mathrm{a}}$ & $9.53^{\mathrm{a}}$ & $36.8^{\mathrm{a}}$ & $44.60^{\mathrm{a}}$ \\
\hline$T_{7}$ & $102.65^{\mathrm{a}}$ & $9.38^{\mathrm{a}}$ & $39.27^{\mathrm{a}}$ & $44.48^{\mathrm{a}}$ \\
\hline$T_{8}$ & $97.77^{\mathrm{a}}$ & $9.40^{\mathrm{a}}$ & $34.87^{\mathrm{ab}}$ & $44.72^{\mathrm{a}}$ \\
\hline$T_{9}$ & $101.38^{\mathrm{a}}$ & $9.65^{\mathrm{a}}$ & $40.4^{\mathrm{a}}$ & $43.27^{\mathrm{a}}$ \\
\hline Grand mean & 95.55 & 9.18 & 37 & 43.48 \\
\hline$F$-probability & $<0.001$ & 0.002 & 0.034 & $<0.001$ \\
\hline $\operatorname{SEM}( \pm)$ & 2.267 & 0.360 & 2.9 & 0.244 \\
\hline $\mathrm{LSD}_{0.05}$ & 6.798 & 1.078 & 8.6 & 0.732 \\
\hline $\mathrm{CV}(\%)$ & 4.1 & 6.8 & 13.5 & 1 \\
\hline
\end{tabular}

$\mathrm{SEM}=$ standard error of mean; $\mathrm{CV}=$ coefficient of variation. Means followed by difference letters are significantly different among each other on DMRT at 5\% level of significance.

was obtained by Yang et al. [15] because of the incorporation of green manure along with a recommended dose of chemical fertilizers.

3.1.2. Spike Length and Number of Grains/Spike. The spike length ranged from $7.47 \mathrm{~cm}$ to $9.79 \mathrm{~cm}$. There was no significant difference in the spike length between the solely chemical fertilizers-treated plots and the green manure-with chemical fertilizers-treated plots. The number of grains per spike ranged from 26 to 40 . There was also no significant difference in the number of grains per spike between the green manure-with chemical fertilizer-treated plots and the only-chemical fertilizers-treated plots. However, the highest number of grains per spike (41) was recorded from $T_{5}$ (the plot with sun hemp incorporation), which was statistically at par with $T_{2}$ (recommended dose of fertilizers), $T_{4}$ (dhaincha), $T_{6}$ (cowpea), and $T_{7}$ (black gram).

3.1.3. 1000-Grain Weight. The 1000-grain weight of wheat was statistically affected by pre-rice green manuring treatments. All green manuring treated plots significantly improved the test weight of wheat compared to summer fallow with only chemical fertilizers treated plot. The highest test weight (44.72 g) was obtained from mung bean $\left(T_{8}\right)$ with a recommended dose of fertilizers and the lowest $(40.37 \mathrm{~g})$ was from the fallow plots without nutrients application $\left(T_{1}\right)$. The 1000-grain weights significantly improved by $3.75 \%, 3.71 \%$, and $3.48 \%$ because of the incorporation of pre-rice mung bean, sun hemp, and cowpea along with a recommended dose of fertilizers as compared to a summer fallow plot with chemical fertilizers $\left(T_{2}\right)$. The effect of chemical fertilizers and green manure treatments on the plant height, spike length, number of grains/ spike, and 1000-grain weight is shown in Table 4.

3.1.4. Grain Yield. Compared with the only-chemical fertilizers-treated plots, the application of chemical fertilizers with green manure surged the wheat yield. The maximum grain yield (5.870 t/ha) was obtained from black gram with a recommended dose of fertilizers $150: 50: 50 \mathrm{~kg} / \mathrm{ha}\left(T_{7}\right)$, which was statistically at par with all other green manuretreated plots. The increment in the grain yield with the incorporation of black gram $\left(T_{7}\right)$ was $39.76 \%$ compared to summer fallow with only chemical fertilizers-treated plot $\left(T_{2}\right)$. The sun hemp $\left(T_{5}\right)$ and mung bean $\left(T_{8}\right)$-treated plots with a recommended dose of fertilizers increased the grain yield by $31.30 \%$ and $30.42 \%$, respectively, as compared to the only-chemical fertilizers-treated plot $\left(T_{2}\right)$. A similar result was found in [16]. Between the legumes as well, the black gram-treated plot with the recommended doses of fertilizers $\left(T_{7}\right)$ increased the yield by $22.3 \%$ compared to the rice beantreated plot with a recommended dose of fertilizers $\left(T_{9}\right)$. This may be because of the rapid decomposition of green manures. It quickly released the nutrient and increased the nutrients availability to the plants, which increased the growth parameters. A similar result was obtained by [12]. Indeed, the incorporation of legumes green manuring increased the uptake of the essential plant nutrients, including micronutrients, such as zinc $(\mathrm{Zn})$, iron (Fe), manganese $(\mathrm{Mn})$, and copper $(\mathrm{Cu})$, which might be the possible reason for a higher grain yield. The incorporation of dhaincha and cowpea green manures increased the yield of the first (rice) and second (maize) succeeding crops by $21 \%$ and $4 \%$ in the first year and by $38 \%$ and $13 \%$ in the second year of the experiment done at Selangor, Malaysia [14]. A similar result was obtained by [15] because of the incorporation of green manure along with the recommended dose of chemical fertilizers. The results were also in line with Pandey and Bista [17], where they observed that the incorporation of mung bean before rice significantly increased the rice yield while sowing rice after wheat. Similarly, research conducted at Indian Agriculture Research Institute [18] suggested that the incorporation of pre-rice green manuring sun hemp, dhaincha, cowpea along with $120,26,33$, and $5 \mathrm{~kg} / \mathrm{ha}$ of nitrogen, phosphorus, potassium, and zinc fertilization $(5 \mathrm{~kg} / \mathrm{ha})$ had a significant residual influence on the wheat yield as compared to summer fallow. The pre-rice 
TABLE 5: Effect of chemical fertilizers and green manure treatments on grain yield and straw yield.

\begin{tabular}{lcc}
\hline Treatments & Grain yield (t/ha) & Straw yield (t/ha) \\
\hline$T_{1}$ & $1.447^{\mathrm{d}}$ & $1.77^{\mathrm{d}}$ \\
$T_{2}$ & $4.2^{\mathrm{b}}$ & $7.547^{\mathrm{ab}}$ \\
$T_{3}$ & $2.762^{\mathrm{c}}$ & $3.567^{\mathrm{c}}$ \\
$T_{4}$ & $5.183^{\mathrm{ab}}$ & $7.843^{\mathrm{ab}}$ \\
$T_{5}$ & $5.515^{\mathrm{a}}$ & $8.160^{\mathrm{a}}$ \\
$T_{6}$ & $5.003^{\mathrm{ab}}$ & $6.510^{\mathrm{b}}$ \\
$T_{7}$ & $5.870^{\mathrm{a}}$ & $7.510^{\mathrm{ab}}$ \\
$T_{8}$ & $5.478^{\mathrm{a}}$ & $7.563^{\mathrm{ab}}$ \\
$T_{9}$ & $4.796^{\mathrm{ab}}$ & $7.033^{\mathrm{ab}}$ \\
Grand mean & 4.38 & 6.39 \\
$F_{-}$probability & $<0.001$ & $<0.001$ \\
SEM \pm$)$ & 0.339 & 0.485 \\
LSD $_{0.05}$ & 1.017 & 1.455 \\
CV \% & 13.1 & 13.2 \\
\hline
\end{tabular}

$\mathrm{SEM}=$ standard error of mean; $\mathrm{CV}=$ coefficient of variation. Means followed by difference letters are significantly different among each other on DMRT at a $5 \%$ level of significance.

amalgamation of legumes may increase the availability of nitrogen and required essential nutrients. It might improve the soil's physicochemical and biological characteristics that lead to an increase in the grain yield $[19,20]$.

The incorporation of dhaincha green manure after 50 and 70 days of sowing along with $75 \%$ of the recommended dose of the nitrogen chemical fertilizers results in a higher BRRI dhan 28 yield [21]. Similarly, using dhaincha and mung bean as pre-rice green manuring along with the application of $75 \%$ of the nitrogen fertilizers was found effective to increase the yield of BINA dhan7 [16].

3.1.5. Straw Yield. The straw yield ranges from 1.77 to $8.16 \mathrm{t} /$ ha. There was no significant residual effect of green manuring with the chemical fertilizers-treated plots and onlychemical fertilizers-treated plot on the straw yield in the ricewheat cropping system. The sun hemp-treated plot with the recommended dose of fertilizers results in a maximum straw yield of $8.160 \mathrm{t} / \mathrm{ha}\left(T_{7}\right)$ followed by dhaincha $\left(T_{4}\right)$. The increment in straw yield with a recommended dose of fertilizers and sun hemp $\left(T_{5}\right)$ was $8.12 \%$ as compared to summer fallow with only chemical fertilizers applied plot $\left(T_{2}\right)$. The effect of chemical fertilizers and green manure treatments on the grain and straw yield of wheat is shown in Table 5.

\subsection{Effect on Soil Chemical Properties}

3.2.1. Effect on Soil Available Phosphorus (P) before and after Harvest. The soil available phosphorus before and after the experiment was significantly affected by the incorporation of green manures. The highest available phosphorus was observed from the incorporation of rice bean $(0.05807 \mathrm{ppm})$ before wheat sowing. There was an increase in soil available phosphorus by $41 \%, 30.9 \%$, and $37.39 \%$ in rice bean, mung bean, and dhaincha-treated plots with the recommended dose of chemical fertilizers as compared to the traditional rice-wheat cropping system $\left(T_{2}\right)$. The same trend was found even after the harvest of wheat. The plots with the incorporation of rice bean and mung bean green manuring significantly increased the soil available phosphorus by $28.88 \%$ and $18.31 \%$ than the summer fallow with onlychemical fertilizers-treated plot $\left(T_{2}\right)$. Dhaincha, sun hemp, mung bean, and rice bean residues contributed to improving the concentration of soil available phosphorus. The secretion of organic acids, breakdown of organophosphatic compounds, and the conversion of the organic phosphate to an inorganic form results in the release of more phosphorus that would be available to the soil [22]. The rapid decomposition of biomass residues produced organic acids which is the major source of available soil phosphorus for plant uptake and directly linked to the productivity of crops. The green manure consists of adequate nutrients, such as phosphorus, which is immediately released into the soil after the decomposition process may be the attributing factor for more available phosphorus in soil. The same results of an increase in the soil available phosphorus were found by Adekiya et al. [4] in green manuring-incorporated plots relative to the only-chemical fertilizer-applied plots. The application of chemical fertilizers releases the phosphorus nutrients that are absorbed by the wheat crop and thus have a better performance than the control. A similar result was observed by Kumar and Prasad [23]. Sometimes, the phosphorus availability may not increase because of the incorporation of green manuring as the microbial population competes for the available phosphorus in the soil. The experiment in rice showed that the application of rock phosphate in green manuring-treated plots significantly increased the soil available phosphorus [24]. Bah et al. [25] reported that the green manure markedly increased the efficiency of the phosphorus fertilizer by (3-39) \% in combination with the chemical fertilizers, and it could increase the concentration of phosphorus in the soil. According to the findings of Prasad and Misra, [26] the three-year experiment with the application of mung bean, organic residues, cowpea, dhaincha, and farmyard manure had a significant influence on the soil sodium bicarbonate extractable phosphorus in both years' rice harvest. Ahlawat et al. [27] reported that incorporating mung bean as green manuring or its residues into the soil after harvesting the pods increases the organic matter content and concentration of phosphorus availability in the soil. Mann et al. [28] also suggested that the incorporation of dhaincha green manure increased the organic matter content and phosphorus content of the soil.

3.2.2. Effect on Soil Available Potassium (K) before and after Harvest. The soil available potassium content was significantly $(P<0.001)$ affected with the green manure treatment. Before the harvest of wheat, the maximum available soil potassium was recorded $(11.867 \mathrm{ppm})$ in the dhainchatreated plot $\left(T_{4}\right)$, which was significantly different from the only-chemical fertilizers-treated plot. There was a $45.78 \%$ and $13 \%$ increase in the soil available potassium in dhaincha $\left(T_{4}\right)$ and rice bean $\left(T_{9}\right)$ plots with a recommended dose of 
TABLE 6: Effect on soil potassium content before and after the wheat harvest.

\begin{tabular}{|c|c|c|c|c|}
\hline Treatments & Before P (ppm) & After P (ppm) & Before K (ppm) & After K (ppm) \\
\hline$T_{1}$ & $0.025^{\mathrm{d}}$ & $0.0173^{\mathrm{e}}$ & $6.49^{\mathrm{d}}$ & $6.23^{\mathrm{d}}$ \\
\hline$T_{2}$ & $0.04^{\mathrm{bc}}$ & $0.04733^{\mathrm{cd}}$ & $8.14^{\mathrm{c}}$ & $8.04^{c}$ \\
\hline$T_{3}^{2}$ & $0.05^{\mathrm{a}}$ & $0.04133^{\mathrm{d}}$ & $8.96^{\mathrm{bc}}$ & $8.20^{c}$ \\
\hline$T_{4}^{3}$ & $0.06^{\mathrm{a}}$ & $0.05233^{\mathrm{bc}}$ & $11.86^{\mathrm{a}}$ & $8.76^{\mathrm{ab}}$ \\
\hline$T_{5}$ & $0.05^{\mathrm{a}}$ & $0.044^{\mathrm{d}}$ & $8.73^{\mathrm{bc}}$ & $9.21^{\mathrm{a}}$ \\
\hline$T_{6}$ & $0.04^{\mathrm{bc}}$ & $0.05067^{b c}$ & $8.73^{b c}$ & $8.79^{\mathrm{ab}}$ \\
\hline$T_{7}^{\circ}$ & $0.04^{\mathrm{c}}$ & $0.04267^{\mathrm{d}}$ & $8.42^{\mathrm{bc}}$ & $8.40^{\mathrm{bc}}$ \\
\hline$T_{8}$ & $0.05^{\mathrm{a}}$ & $0.056^{\mathrm{ab}}$ & $9.02^{\mathrm{bc}}$ & $8.48^{\mathrm{bc}}$ \\
\hline$T_{9}^{\circ}$ & $0.06^{\mathrm{a}}$ & $0.061^{\mathrm{a}}$ & $9.20^{\mathrm{b}}$ & $9.02^{\mathrm{a}}$ \\
\hline Grand mean & 0.05 & 0.05 & 8.84 & 8.35 \\
\hline$F$-probability & $<0.001$ & $<0.001$ & $<0.001$ & $<0.001$ \\
\hline $\operatorname{SEM}( \pm)$ & 0.002 & 0.002 & 0.28 & 0.15 \\
\hline $\mathrm{LSD}_{0.05}$ & 0.006 & 0.006 & 0.83 & 0.45 \\
\hline $\mathrm{CV} \%$ & 7.5 & 7 & 5.4 & 3.1 \\
\hline
\end{tabular}

SEM = standard error of mean; $\mathrm{CV}=$ coefficient of variation. Means followed by difference letters are significantly different among each other on DMRT at a $5 \%$ level of significance.

fertilizers as compared to the only-chemical fertilizers' application $\left(T_{2}\right)$. However, after the harvest of wheat, the maximum soil available potassium was recorded (9.217 ppm) on the sun hemp $\left(T_{5}\right)$-treated plot, which was significantly different from the only-chemical fertilizerstreated plot. Along with the organic matter, green manuring provides mineral nutrients, such as potassium, required for the growth of crops. A similar result was found by [4]. Green manuring decomposition releases potassium by the recycling process as per Singh et al. [29]. There could be better root growth because of the addition of organic matter with the incorporation of dhaincha, which further helps in the uptake of potassium by the plants as per Schumann et al. [30]. In the same way, green manuring enhances the microbial action which speed up the decomposition process and increases the availability of potassium to plants as per Eriksen [31]. There was also an increase in the available potassium because of the application of chemical fertilizers in combination with green manuring by Kumar and Prasad [23]. The effect on the available soil phosphorus and potassium before and after the harvest of wheat is shown in Table 6.

3.2.3. Effect on Soil Organic Matter (SOM). There was a significant difference in the organic matter content of soil because of the incorporation of different green manure in the pre-rice crop. The sun hemp-incorporated plot with a recommended dose of fertilizers had (3.97\%) an organic matter content that was significantly different from that of the only-chemical fertilizers-treated plot $\left(T_{2}\right)$, whose value is only $2.32 \%$ but is statistically at par with $\left(T_{4}\right),\left(T_{6}\right)$, and $\left(T_{9}\right)$ treatments. The introduction of sun hemp, dhaincha, rice bean, and black gram increased the organic matter content of the soil by $71 \%, 62.93 \%, 55.6 \%$, and $35.77 \%$, respectively as compared to summer fallow with chemical fertilizers applied plot $\left(T_{2}\right)$. A similar trend was found even after the wheat harvest. The decomposition of green manure adds a significant concentration of organic acids, amino acids, sugars, vitamins, organic carbon, and energy to the soil microorganisms, which enhances the decomposition process and adds organic matter after they die. They are the possible factors for an increase in the organic matter content in the soil. The nutrient accumulation in dhaincha was primarily a function of the growing period available for the biomass production [32]. The NPK fertilizers provide the soluble nutrients immediately to the plant and lack the decomposing materials for further decomposition, which results in no addition of organic matter for forming a better soil structure [4]. The findings agree with [33]. Salahin et al., [14] suggested that the incorporation of sesbania green manuring in the maize-rice cropping system increased the organic matter content as compared to the control plots. The possible reason for the increase in the organic matter content is the addition of more biomass. The soil microbial biomass, nitrogen, and carbon significantly increased because of the legume crop residue incorporation, which could directly enhance the organic matter content [34]. The soil organic carbon plays a vital role in the formation of stable soil aggregates, and it increases the water holding capacity of the soil. It acts as a nutrient pool that contributes to sustainable agriculture [35]. In general, the legume crop residue incorporation increases the soil labile organic carbon, which is an important form of soil organic matter [36].

Several authors reported that the integration of various green manures increased the soil organic matter [37, 38]. Dhaincha incorporation enhances the concentration of organic matter and soluble phosphorus in the soil as per the study of Mann [39]. The organic matter is increased because of the application of more biomass and its rapid decomposition [40]. The increase in the levels of the organic matter is associated with treating the soils with crop residues. This observation agrees with those made by Ogbodo [33], Demir, and Gülser [41]. A similar result was found by Rixon [42], where mung bean had a significant effect on the organic carbon of soil. The decomposition of mung bean residue formed a product that acts as a binding agent. It supported the formation of stable soil aggregates and increased carbon storage. 
TABLE 7: Soil nitrogen and organic matter content before and after wheat harvest.

\begin{tabular}{|c|c|c|c|c|}
\hline Treatments & Before SOM (\%) & After SOM (\%) & Before N (\%) & After N (\%) \\
\hline$T_{1}$ & $1.41^{\mathrm{e}}$ & $0.84^{\mathrm{e}}$ & $0.05^{\mathrm{d}}$ & $0.04^{\mathrm{c}}$ \\
\hline$T_{2}$ & $2.32^{\mathrm{d}}$ & $0.897^{\mathrm{e}}$ & $0.067^{\mathrm{c}}$ & $0.05^{\mathrm{bc}}$ \\
\hline$T_{3}$ & $2.61^{\mathrm{cd}}$ & $1.877^{\mathrm{ab}}$ & $0.08^{\mathrm{a}}$ & $0.05^{\mathrm{c}}$ \\
\hline$T_{4}^{3}$ & $3.78^{\mathrm{a}}$ & $2.149^{\mathrm{a}}$ & $0.09^{\mathrm{a}}$ & $0.08^{\mathrm{a}}$ \\
\hline$T_{5}$ & $3.97^{\mathrm{a}}$ & $1.286^{\mathrm{d}}$ & $0.08^{\mathrm{abc}}$ & $0.08^{\mathrm{a}}$ \\
\hline$T_{6}$ & $3.44^{\mathrm{ab}}$ & $1.649^{\mathrm{bc}}$ & $0.07^{\mathrm{bc}}$ & $0.08^{\mathrm{a}}$ \\
\hline$T_{7}^{\circ}$ & $3.15^{\mathrm{bc}}$ & $1.411^{\mathrm{cd}}$ & $0.07^{\mathrm{bc}}$ & $0.07^{\mathrm{a}}$ \\
\hline$T_{8}$ & $3.06^{\mathrm{bc}}$ & $1.953^{\mathrm{a}}$ & $0.07^{\mathrm{abc}}$ & $0.07^{\mathrm{a}}$ \\
\hline$T_{9}^{\circ}$ & $3.61^{\mathrm{a}}$ & $1.467^{\mathrm{cd}}$ & $0.08^{\mathrm{ab}}$ & $0.07^{\mathrm{a}}$ \\
\hline Grand mean & 3.04 & 1.50 & 0.073 & 0.066 \\
\hline$F$-probability & $<0.001$ & $<0.001$ & 0.001 & $<0.001$ \\
\hline SEM $( \pm)$ & 0.191 & 0.087 & 0.005 & 0.005 \\
\hline $\mathrm{LSD}_{0.05}$ & 0.573 & 0.26 & 0.014 & 0.014 \\
\hline $\mathrm{CV} \%$ & 10.9 & 10 & 11.4 & 12.5 \\
\hline
\end{tabular}

$\mathrm{SEM}=$ standard error of mean; $\mathrm{CV}=$ coefficient of variation. Means followed by difference letters are significantly different among each other on DMRT at a $5 \%$ level of significance.

3.2.4. Effect on Total Soil Nitrogen (N). The data revealed that there was a significant difference in the soil total nitrogen content with the practice of different types of green manuring. The maximum nitrogen $(0.087 \%)$ content was observed in dhaincha $\left(T_{4}\right)$-treated plot, which was at par with $T_{3}, T_{9}, T_{8}$, and $T_{5}$, respectively, and significantly different than the onlychemical fertilizers-treated plot $\left(T_{2}\right)$. There was an increase in the nitrogen content of the soil with the incorporation of green manure before the preceding crops (rice) and its residual effect on the succeeding wheat crops. The plots treated with green manure showed high nitrogen content. The lowest nitrogen content was $0.047 \%$ in the fallow $\left(T_{1}\right)$. After the harvest, the plots treated with green manure had more nitrogen content as compared to summer fallow with chemical fertilizer application plot. The increase in the soil total nitrogen might be the decomposition of organic residues left after the harvest of crops [43]. There was a $29.85 \%$ and $23.88 \%$ increase in the soil total nitrogen content by the dhaincha and mung bean-treated plots as compared to the only-chemical fertilizer-treated plots. This may be because of an increase in nitrogen mineralization from green manuring, which adds the available nitrogen in the soil $[44,45]$. The combination of green manure and reduced dose of fertilizers significantly increased the soil total nitrogen content as compared to a recommended dose of chemical fertilizer-treated plot in the finding of [15]. The possible reason may be the supplement of green manure nitrogen that significantly contributed to the soil total nitrogen. It might be attributed to the enhanced nitrogen mineralization of the residual organic matter by the green manure having a greater soil microbial biomass nitrogen relative to only chemical fertilizers treated plot. Even after the wheat harvest, a similar trend was observed. The result is in accordance with [4]. Generally, legumes decompose rapidly than non-legumes because of the high content of nitrogen. It results in the addition of nitrogen to the soil after decomposition [46]. The incorporation of crop residues increases microbial immobilization and prevents the loss of nitrogen through leaching. Furthermore, it improves the physical, chemical, and biological features of the soil [47]. The addition of legume crop residues enhances the rapid degradation of residues by the microorganism and increases the easily decomposable organic carbon and nitrogen concentration in the soil [36]. As per [48], the soil microorganisms decompose the legume residues and contribute to the soil total nitrogen.

This result was similar to [49], who found that the nitrogen level in the soil increased especially in the legumesbased cropping system. Instead of a decline, there was a slight increase in the $\mathrm{N}$ level. The possible reason may be the addition of $\mathrm{N}$ through the roots, stubbles, and leaf fall of the legumes, as well as because of the better recycling of nitrogen in the residues. The dhaincha-incorporated plot had a significantly higher nitrogen content than the only-chemical fertilizers-treated plot. It might be the rapid decaying of the incorporated residues and prolific stem nodules. The green manure prevents the loss of nitrogen from urea by maintaining the $\mathrm{pH}$ of flood water and helps to rehabilitate the balance of the nitrogen fertilizer in the soil [50]. A study done at Faizabad, Uttar Pradesh showed that mung bean and black gram shown in the monsoon along with the application of nitrogen have significant residual effects on wheat grown, sequentially. The residual effect of black gram was greater as compared to mung bean [13]. The effect on the soil organic matter content and nitrogen content before and after wheat harvest is shown in Table 7.

3.2.5. Effect on Soil $p H$. The green manure treatments have a less significant effect on the soil $\mathrm{pH}$ before and after the harvest of wheat. The effect of all treatments was statistically at par. After the harvest of rice, the soil $\mathrm{pH}$ was low, especially in the rice-wheat-organic manure $\left(T_{3}\right)$, rice-wheat-dhaincha $\left(T_{4}\right)$, and rice-wheat-mung bean $\left(T_{7}\right)$-treated plots as compared to other plots. However, after the harvest of wheat, there was an increase in the soil $\mathrm{pH}$ in all treatments. A similar result was found by Raju [51] who agree on no change in the soil $\mathrm{pH}$ after the incorporation of green manuring in a short period of time. Regmi et al. [52] also revealed the same results in the multiple-year soil fertility research done at the National Wheat Research Program, Nepal. 


\section{Conclusion}

The green manure has many advantages over the chemical fertilizers as it is easily grown and incorporated into the desired field during the field preparation period. It plays a major role in the improvement of physicochemical and biological features of the soil and has a subsequent contribution to the yield of the following crops. The research done at Regional Agriculture Research Station (RARS), Khajura, revealed that the incorporation of green manures before rice planting has a substantial influence on the chemical properties of the soil, such as its organic matter content, NPK content, grain yield, and yield attributing wheat parameter in the rice-wheat cropping pattern. More specifically, incorporating green manure along with the NPK fertilizers and summer fallow with chemical fertilizers increased the yield of the succeeding wheat crops. However, there was a better improvement in the soil chemical properties (soil organic matter and nitrogen) because of the inclusion of green manure as compared to summer fallow with only chemical fertilizer. The unused summer fallow periods between wheat harvesting and rice transplanting is fruitful for cultivating different legumes and green manures that have a subsequent residual impact on the soil chemical properties and the grain yield of the following wheat crop in the rice-wheat cropping system. As compared to the regular intensive monocropping system, the adoption of green manures in the ricewheat cropping system creates an enabling environment and increase the soil organic matter content. There was no significant change in the soil $\mathrm{pH}$ because of the incorporation of green manure in a short cropping period. Thus, maintaining the soil health and productivity can be furnished by the incorporation of the green manure and the recommended doses of inorganic chemical fertilizers, utilizing the uncultivated period between wheat harvesting and rice transplanting. However, the finding was from a one-year experiment that needs multiyear verifications. In the context of Nepal, a majority of the farmers are poor, and the adoption of green manure at the farm level will make a substantial contribution in increasing the wheat productivity. Also, it contributes to a sustainable rice-wheat production system. Thus, the green manure can be the best alternative for Nepalese farmers to improve the chemical properties and yield at present.

\section{Data Availability}

The original data of the research will be available from the corresponding authors through mail upon request for further information in the future.

\section{Conflicts of Interest}

The authors declare that they have no conflicts of interest.

\section{References}

[1] H. A. Moghaddam, M. Ramroudi, S. A. Koohkan, H. R. Fanaei, and A. A. Moghaddam, "Effects of crop rotation systems and nitrogen levels on wheat yield, some soil properties and weed population," International Journal of AgriScience, vol. 1, no. 3, pp. 156-163, 2011.
[2] B. Kumar and R. P. R. Sharma, "Effect of preceding crops and nitrogen rates on growth, yield and yield attributes of wheat," Indian Journal of Agricultural Research, vol. 34, no. 1, pp. 34-38, 2000.

[3] M. M. Islam, T. A. Urmi, M. S. Rana, M. S. Alam, and M. M. Haque, "Green manuring effects on crop morphophysiological characters, rice yield and soil properties," Physiology and Molecular Biology of Plants, vol. 25, no. 1, pp. 303-312, 2019.

[4] A. O. Adekiya, T. M. Agbede, C. M. Aboyeji, O. Dunsin, and J. O. Ugbe, "Green manures and NPK fertilizer effects on soil properties, growth, yield, mineral and vitamin $\mathrm{C}$ composition of okra (Abelmoschus esculentus (L.) Moench)," Journal of the Saudi Society of Agricultural Sciences, vol. 18, no. 2, pp. 218-223, 2019.

[5] C. Wright, Soil Analysis: A Handbook of Physical and Chemical Methods, London Thomas-Murty and Co., London, UK, 1939.

[6] A. Klute, "Water retention," in Method of Soil Analysis, Part 1, Physical and Mineralization Methods, A. Klute, Ed., Agronomy Society of Americal and Soil Science Society of America, Madison, WI, USA, 2 edition, pp. 635-653, Madison, WI, USA, 1986, Agronomy Monograph 9.

[7] A. Walkley and I. A. Black, "An examination of the Degtjareff method for determining soil organic matter, and a proposed modification of the chromic acid titration method," Soil Science, vol. 37, no. 1, pp. 29-38, 1934.

[8] J. Bremner and C. Mulvaney, "Total nitrogen," in Method of Soil Analysis, A. Page, R. Miller, and D. keeny, Eds., pp. 1119-1123, American Society of Agronomy and Soil Science Society of America, Madison, WI, USA, 1982.

[9] S. Olsen, C. Cole, F. Watanbe, and L. Dean, Estimation of Available Phosphorus in Soils by Extraction with Sodium Bicarbonate, Government Printing Office, Washington, DC, USA, 1954.

[10] M. Jackson, Soil Chemical Analysis, Prentice Hall of India Pvt.ltd, New Delhi, India, 1967.

[11] K. G. Pillai and R. De, "Nutrient uptake of rice varietyJaya at different levels and timings of nitrogen application under two systems of water management," Proceedings: Plant Sciences, vol. 89, no. 4, pp. 257-267, 1980.

[12] A. Nawaz, M. Farooq, R. Lal, A. Rehman, T. Hussain, and A. Nadeem, "Influence of sesbania brown manuring and rice residue mulch on soil health, weeds and system productivity of conservation rice-wheat systems," Land Degradation \& Development, vol. 28, no. 3, pp. 1078-1090, 2017.

[13] D. S. Yadav and S. B. Singh, "Studies on nitrogen economy in legumes based cropping system," Indian Journal of Agronomy, vol. 31, no. 4, pp. 380-383, 1986.

[14] N. Salahin, M. K. Alam, M. M. Islam, L. Naher, and N. M. Majid, "Effects of green manure crops and tillage practice on maize and rice yields and soil properties," Australian Journal of Crop Science, vol. 7, no. 12, p. 1901, 2013.

[15] L. Yang, J. Bai, J. Liu, N. Zeng, and W. Cao, "Green manuring effect on changes of soil nitrogen fractions, maize growth, and nutrient uptake," Agronomy, vol. 8, no. 11, pp. 1-13, 2018.

[16] M. R. Islam, M. B. Hossain, A. B. Siddique, M. T. Rahman, and M. Malika, "Contribution of green manure incorporation in combination with nitrogen fertilizer in rice production," SAARC Journal of Agriculture, vol. 12, no. 2, pp. 134-142, 2014.

[17] B. Pandey and N. Bista, "Inclusion of legumes in rice-wheat system as crop diversification under conventional and zero tillage in Western Terai, Nepal," in Proceedings of the 28th 
National Summer Crops Workshop, pp. 335-339, National Rice Research Program (NRRP) Hardinath, Nepal, March 2015.

[18] A. Singh and Y. S. Shivay, "Residual effect of summer green manure crops and $\mathrm{Zn}$ fertilization on quality and $\mathrm{Zn}$ concentration of durum wheat (Triticum durum Desf.) under a Basmati rice-durum wheat cropping system," Biological Agriculture and Horticulture, vol. 29, no. 4, pp. 271-287, 2013.

[19] P. S. Bisht, P. C. Pandey, and D. K. Singh, "Effect of different sources of nutrients on rice (Oryza sativa) yield and soil nutrient status in rice-wheat cropping," in Proceedings of the National Symposium on Conservation Agriculture and Environment, p. 28, Banaras Hindu University, Varanasi, India, October 2006.

[20] V. Pooniya and Y. S. Shivay, "Effect of green manuring and zinc fertilization on productivity and nutrient uptake in basmati rice (Oryza sativa)-wheat (Triticum aestivum) cropping system," Indian Journal of Agronomy, vol. 56, no. 1, pp. 28-34, 2011.

[21] M. Islam, Z. Ryhana, M. Hoque, A. Huda, and M. Begum, "Residual effect of green manure on the growth and yield of BRRI dhan28," Journal of Environmental Science and Natural Resources, vol. 9, no. 1, pp. 35-40, 2016.

[22] V. Evangelia, D. Anthoula, P. Pericles, J. Avramides Elizabeth, and A. Dimitris, "Comparative study for the control of organic agriculture in a region of Greece in 17," in Proceedings of the World Congress of Soil Science, pp. 14-21, Bangkok, Thailand, August 2002.

[23] V. Kumar and R. K. Prasad, "Integrated effect of mineral fertilizers and green manure on crop yield and nutrient availability under rice-wheat cropping system in calciorthents," Journal of the Indian Society of Soil Science, vol. 56, no. 2, pp. 209-214, 2008.

[24] M. A. Cavigelli and S. J. Thien, "Phosphorus bioavailability following incorporation of green manure crops," Soil Science Society of America Journal, vol. 67, no. 4, pp. 1186-1194, 2003.

[25] A. R. Bah, A. R. Zaharah, and A. Hussin, "Phosphorus uptake from green manures and phosphate fertilizers applied in an acid tropical soil," Communications in Soil Science and Plant Analysis, vol. 37, no. 13-14, pp. 2077-2093, 2006.

[26] R. Prasad and B. N. Misra, "Effect of addition of organic residues, farmyard manure and fertilizer nitrogen on soil fertility in rice-wheat cropping system," Archives of Agronomy and Soil Science, vol. 46, no. 5-6, pp. 455-463, 2001.

[27] I. P. S. Ahlawat, M. Ali, R. L. Yadav, J. D. V. K. Rao, T. J. Rego, and R. P. Singh, "Biological nitrogen fixation and residual effect of summer and rainy season grain legumes in rice and wheat cropping systems of the Indo-Gangetic Plain," Residual Effects of Legumes in Rice and Wheat Cropping Systems of the IndoGangetic Plains, Oxford/IBH Publishing Co., vol. 5, no. 3, pp. 31-54, New Delhi, India, 1998.

[28] R. A. Mann, M. S. Zia, and M. Saleem, "An improved green manure technology for sustaining the wheat rice system," Quarterly Science Vision, vol. 6, no. 2, p. 53, 2000.

[29] S. Singh, N. Ghoshal, and K. P. Singh, "Synchronizing nitrogen availability through application of organic inputs of varying resource quality in a tropical dryland agroecosystem," Applied Soil Ecology, vol. 36, no. 2-3, pp. 164-175, 2007.

[30] R. A. Schumann, J. H. Meyer, and R. Van Antwerpen, "A Review of Green Manuring Practices in Sugarcane Production," in Proceedings of the Annual Congress-South African Sugar Technologists' Association, pp. 93-100, Kwa-Shukela, South Africa, January 2000.
[31] J. Eriksen, "Gross sulphur mineralisation-immobilisation turnover in soil amended with plant residues," Soil Biology and Biochemistry, vol. 37, no. 12, pp. 2216-2224, 2005.

[32] Y. K. Latt, A. K. Myint, T. Yamakawa, and K. Ogata, "The effects of green manure (Sesbania rostrata) on the growth and yield of rice," Journal of the Faculty of Agriculture, Kyushu University, vol. 54, no. 2, pp. 313-319, 2009.

[33] E. N. Ogbodo, "Effect of crop residue on soil chemical properties and rice yield on an Ultisol at Abakaliki, Southeastern Nigeria," World Journal of Agricultural Sciences, vol. 7, no. 1, pp. 13-18, 2011.

[34] X. Zhou, H. Wu, G. Li, and C. Chen, "Short-term contributions of cover crop surface residue return to soil carbon and nitrogen contents in temperate Australia," Environmental Science and Pollution Research, vol. 23, no. 22, pp. 2317523183, 2016.

[35] X. Liu, S. J. Herbert, A. M. Hashemi, X. f. Zhang, and G. Ding, "Effects of agricultural management on soil organic matter and carbon transformation-a review," Plant Soil and Environment, vol. 52, no. 12, pp. 531-543, 2006.

[36] F. Coppens, R. Merckx, and S. Recous, "Impact of crop residue location on carbon and nitrogen distribution in soil and in water-stable aggregates," European Journal of Soil Science, vol. 57, no. 4, pp. 570-582, 2006.

[37] G. Herrera-Arreola, Y. Herrera, and L. Dendooven, "Mesquite (Prosopis juliflora (Sw.) DC.), huisache (Acacia farnesiana (L.) Willd.) and catclaw (Mimosa biuncifera Benth.) and their effect on dynamics of carbon and nitrogen in soils of the semiarid highlands of Durango Mexico," Journal of Arid Environments, vol. 69, pp. 583-598, 2007.

[38] U. K. Mandal, G. Singh, U. S. Victor, and K. L. Sharma, "Green manuring: its effect on soil properties and crop growth under rice-wheat cropping system," European Journal of Agronomy, vol. 19, no. 2, pp. 225-237, 2003.

[39] R. A. Mann, Crop Husbandry: Green Manuring as a Soil Fertility Build-Up Tool in Wheat-Rice Cropping Sequences, Pakistan Agriculture, Pakistan, 1988.

[40] G. Sarwar, H. Schmeisky, N. Hussain, S. Muhammad, M. Ibrahim, and E. Safdar, "Improvement of soil physical and chemical properties with compost application in rice-wheat cropping system," Pakistan Journal of Botany, vol. 40, no. 1, pp. 275-282, 2008.

[41] Z. Demir and C. Gülser, "Effects of rice husk compost application on soil quality parameters in greenhouse conditions," Eurasian Journal of Soil Science (Ejss), vol. 4, no. 3, pp. 185-190, 2015.

[42] A. J. Rixon, "Soil fertility changes in a red-brown earth under irrigated pastures. I. Changes in organic carbon/nitrogen ratio, cation exchange capacity and $\mathrm{pH}$," Australian Journal of Agricultural Research, vol. 17, no. 3, pp. 317-325, 1966.

[43] G. Abera, E. Wolde-meskel, and L. R. Bakken, "Carbon and nitrogen mineralization dynamics in different soils of the tropics amended with legume residues and contrasting soil moisture contents," Biology and Fertility of Soils, vol. 48, no. 1, pp. 51-66, 2012.

[44] M. J. Mulvaney, C. W. Wood, K. S. Balkcom, D. A. Shannon, and J. M. Kemble, "Carbon and nitrogen mineralization and persistence of organic residues under conservation and conventional tillage," Agronomy Journal, vol. 102, no. 5, pp. 1425-1433, 2010.

[45] A. Perin, R. H. S. Santos, S. S. Urquiaga, P. R. Cecon, J. G. M. Guerra, and G. B. D. Freitas, "Sunnhemp and millet as green manure for tropical maize production," Scientia Agricola, vol. 63, no. 5, pp. 453-459, 2006. 
[46] S. Xu, L. L. Liu, and E. J. Sayer, "Variability of above-ground litter inputs alters soil physicochemical and biological processes: a meta-analysis of litterfall-manipulation experiments," Biogeosciences, vol. 10, no. 11, pp. 7423-7433, 2013.

[47] H. Blanco-Canqui and R. Lal, "Crop residue removal impacts on soil productivity and environmental quality," Critical Reviews in Plant Sciences, vol. 28, no. 3, pp. 139-163, 2009.

[48] C. R. Chen and Z. H. Xu, "Analysis and behavior of soluble organic nitrogen in forest soils," Journal of Soils and Sediments, vol. 8, no. 6, pp. 363-378, 2008.

[49] P. K. R. Nair, A. Singh, and S. C. Modgal, "Maintenance of soil fertility under intensive multiple cropping in northern India," Indian Journal of Agricultural Sciences, vol. 43, pp. 805-881, 1973.

[50] K. H. Diekmann, S. K. De Datta, and J. C. G. Ottow, "Nitrogen uptake and recovery from urea and green manure in lowland rice measured by $15 \mathrm{~N}$ and non-isotope techniques," Plant and Soil, vol. 148, no. 1, pp. 91-99, 1993.

[51] A. P. Raju, Study of Soil Structure in Different Crop Rotations with Paddy as One of the Crops, IARI, Division of Agricultural Physics, New Delhi, India, 1967.

[52] A. Regmi, T. Kharel, and L. Shresth, "Management of Sesbania and its effect on rice-wheat system," in Proceedings of the Rice Research, pp. 298-305, Khumaltar-Lalitpur, Nepal, 2004. 